\title{
PENERAPAN MODEL PEMBELAJARAN TWO STAY TWO STRAY (TS-TS) TERHADAP KEMAMPUAN MENGANALISIS PUISI "KARANGAN BUNGA" KARYA TAUFIQ ISMAIL SISWA KELAS X SMK PAB 3 MEDAN ESTATE
}

\author{
Rika Kartika
Jurusan Pendidikan Bahasa dan Sastra Indonesia
Pascasarjana Universitas Negeri Medan \\ Rika_kartika39@yahoo.com
}

\begin{abstract}
Abstrak. Tujuan penelitian ini adalah Mendeskripsikan model pembelajaran two say two stray terhadap menganalisis puisi "Karangan bunga" karya Taufiq Ismail kelas $x$ smk PAB 3 Medan Estate. Model pembelajaran two stay to stray (TS-TS) dikembangkan oleh spencer kagan (1980). Model ini bisa digunakan dalam seтиa mata pelajaran dan untuk semиa tingkatan usia peserta didik. Model TS-TS merupakan sistem pembelajaran kelompok dengan tujuan agar siswa dapat saling bekerja sama, bertanggung jawab, salaing membantu memecahkan masalah, dan saling mendorong satu sama lain untuk berprestasi. Metode ini juga melatih siswa untuk bersosialisasi dengan baik. Populasi adalah siswa kelas $X$ yang berjumlah 80 orang, sebagai total sampling sebanyak 80 orang dan dibagi menjadi dua kelompok yaitu kelompok kelas kontrol dan kelompok eksperimen. Model yang digunakan dalam penelitian ini adalah metode eksperimen yaitu metode two group design post-test. Instrumen yang digunakan adalah esay tes atau tes tertulis yaitu menganalisis puisi "karangan bunga" karya Taufiq Ismail. Dari hasil pengolahan data diperoleh rata-rata kelas eksperimen adalah 76,87 dengan standar deviasi 9,90, sedangkan kelas kontrol 56 dengan standar deviasi 8,15. Dengan demikian dapat dikatakan bahwa nilai kelas eksperimen lebih tinggi dari kelas kontrol. Setelah dilakukan pengujian hipotesis diperoleh $t_{\text {hitung }}=10,33$ selanjutnya dikonsultasikan dengan $t_{\text {tabel }}$ pada taraf signifikan $5 \%$ dengan dk $=\left(n_{1}+n_{2}\right)-2=(40+40-2)=78$, maka diperoleh taraf signifikan 5\% $=1,982$ (dengan interpolasi). Kemudian dibandingkan antara $t_{\text {hitung }}$ dengan $t_{\text {tabel }}$ diperoleh $t_{\text {hitung }}>t_{\text {tabel }} 10,33>$ 1,982 sehingga dapat disimpulkan bahwa Ha diterima yaitu menyatakan bahwa model two say two stray dapat diterapkan untuk meningkatkan kemampuan siswa dalam menganalisis puisi "Karangan Bunga" karya Taufiq Ismail pada siswa kelas X SMK PAB 3 Medan Estate.
\end{abstract}

Kata Kunci : Model Pembelajaran Two Say Two Stray (TS-TS), Menganalisis Puisi, Karangan Bunga

\section{PENDAHULUAN}

Dalam dunia pendidikan pembelajaran bahasa Indonesia, perlu ditekankan dari sejak dini hingga pada pendidikan tinggi. Salah satu pelajaran yang perlu dibina di dalam sekolah adalah bahasa Indonesia. Dalam pembelajaran bahasa Indonesia guru bertanggung jawab untuk melaksanakan dan merencanakan pengajaran di sekolah dengan menerapkan teori yang melibatkan siswa untuk berpartisipasi aktif demi tercapainya tujuan pengajaran. Dalam pembelajaran bahasa Indonesia terdapat empat keterampilan berbahasa yakni keterampilan berbicara, keterampilan membaca, keterampilan menyimak, dan keterampilan menulis.

Karya sastra merupakan sebuah struktur. Struktur di sini dalam arti bahwa karya sastra itu merupakan susunan unsur-unsur yang bersistem 
antara unsur-unsurnya terjadi hubungan timbal balik, saling menentukan. Dalam pengertian struktur ini (Piaget via Hawkes, 1978:16) terlihat adanya rangkaian kesatuan yang meliputi tiga dasar, yaitu ide kesatuan, ide transformasi, dan ide pengaturan diri sendiri (self- regulation).

Pertama, struktur itu merupakan keseluruhan bulat, yaitu bagian-bagian yang membentuknya tidak dapat berdiri sendiri di luar struktur itu. Kedua,struktur itu berisi gagasan transformasi dalam arti bahwa struktur itu tidak statis. mampu melakukan prosedurprosedur transformasional, dalam arti bahanbahan baru diproses dengan proses dengan prosedur dan melalui prosedur itu .Strukturalisme itu pada dasarnya merupakan cara berpikir tentang dunia terutama berhubungan dengan tanggapan dan deskripsi struktur-struktur.

Menurut E. Kosasi (2011:206), "Puisi adalah bentuk karya sastra yang menggunakan kata - kata yang indah dan kaya makna". Keindahan sebuah puisi disebabkan oleh diksi, majas, rima dan irama yang terkandung dalam sebuah karya satra itu".

Herman J.Waluyo(2005:1) mendefinisikan bahwa "Puisi adalah karya sastra yang dipadatkan, dipersingkat, dan diberi irama dengan bunyi yang padu dan pemilihan katakata kias (imajinatif)".

Pembelajaran menganalisi puisi adalah pembelajaran yang sangat sulit bagi siswa. terbukti berdasarkan hasil interview yang dilakukan oleh peneliti dengan guru Bahasa Indonesia SMK PAB 3 Medan Estate bahwa, masih banyak siswa yang tidak mampu untuk menganalisis puisi. Kemudian, masih banyak siswa yang mendapatkan nilai dibawah KKM. Menurut beliau siswa kurang berminat dalam pembelajaran menganalisis puisi.

Berdasarkan uraian di atas, penulis tertarik untuk melakukan sebuah penelitian yang berjudul "Penerapan Model pemebelajaran Two Stay Two Stray (TS-TS) terhadap kemampuan menganalisis puisi "Karangan Bunga" Karya Taufiq Ismail Kelas X SMK PAB 3 Medan Estate".

\section{KAJIAN TEORI}

\section{Pengertian Puisi}

Puisi dari bahasa Yunani kuno adalah seni tertulis dan bahasa digunakan kualitas estetiknya untuk tambahan, atau selain arti semantiknya. Puisi adalah karya sastra tertulis yang paling awal ditulis oleh manusia. Puisi memiliki kata-kata yang betul-betul terpilih agar memiliki kekuatan pengucapan. Walaupun singkat atau padat, namun berkekuatan.

Puisi adalah bentuk karya sastra yang menggunakan kata - kata yang indah dan kaya makna. Keindahan sebuah puisi disebabkan oleh diksi, majas, rima dan irama yang terkandung dalam karya sastra itu. Adapun kekayaan makna yang terkandung dalam puisi dikarenakan oleh pemadatan segala unsur bahasa berbeda dengan yang digunakan sehari-hari. Puisi menggunakan 
bahasa yang ringkas, namun maknanya sangat kaya. Kata-kata yang digunakan adalah katakata konotatif, yaitu mengandung banyak penafsiran dan pengertian.

Puisi adalah bentuk karya sastra yang mengungkapkan pikiran dan perasaan penyair secara imajinatif dan disusun dengan mengonsentrasikan semua kekuatan bahasa dengan pengonsentrasian struktur fisik dan struktur batinnya. Puisi adalah karya sastra tertulis yang paling awal ditulis oleh manusia.

Menurut Kamus Besar Bahasa Indonesia (2005) menyatakan bahwa "Puisi adalah ragam bahasa yang bahasanya terikat oleh irama,mantra, rima, serta penyusunan larik dan bait". Menurut Jakob Sumardjo dan Saini K.M (1987:122) menyatakan bahwa, "Puisi adalah suatu karya sastra yang meminta ditelaah secara nalar".

Menurut E. Kosasi (2011:206), "Puisi adalah bentuk karya sastra yang menggunakan kata - kata yang indah dan kaya makna". Keindahan sebuah puisi disebabkan oleh diksi, majas, rima dan irama yang terkandung dalam sebuah karya satra itu".

Herman J. Waluyo (2005:1) mendefinisikan bahwa "Puisi adalah karya sastra yang dipadatkan, dipersingkat, dan diberi irama dengan bunyi yang padu dan pemilihan katakata kias (imajinatif)".

Balai Pustaka (1994:150), "Puisi adalah gubahan bahasa yang bentuknya dipilih dan ditata secara cermat sehingga mempertajam kesadaran akan pengalaman membangkitkan tanggapan khusus lewat penataan bunyi, irama, dan makna khusus".

Berdasarkan definisi di atas maka dapat disimpulkan bahwa puisi merupakan suatu karya seni yang didalamnya terdapat imajinasi, gaya bahasa, diksi, perasaan, dan memiliki makna. Puisi merupakan karya sastra yang mengungkapkan kata - kata yang bersifat konotatif dan disusun secara imajinatif sehingga dapat menghasilkan sebuah karya sastra yang memiliki makna.

\section{Model Pembelajaran Two Stay to Stray}

Model pembelajaran two stay to stray (TS-TS) dikembangkan oleh spencer kagan (1980). Model ini bisa digunakan dalam semua mata pelajaran dan untuk semua tingkatan usia peserta didik. Model TSTS merupakan sistem pembelajaran kkelompok dengan tujuan agar siswa dapat saling bekerja sama, bertanggung jawab, salaing membantu memecahkan masalah, dan saling mendorong satu sama lain untuk berprestasi. Model ini juga melatih siswa untuk bersosialisasi dengan baik.

$$
\text { Menurut Miftahul }
$$$$
\text { (2014:207) }
$$
menyatakan bahwa dalam model pembelajaran Two Stay Two Stray adapun langkah-langkah yang harus dilaukukan dalam menerapkan model tersebut sebagai berikut:

1. Guru membagi siswa dalam beberapa kelompok yang setiap kelompoknya terdiri dari empat siswa. Kelompok yang dibentuk merupakakn elompok 
heterogen, misalnya satu kelompok trdiri dari 1 siswa berkemampuan tingi, 2 siswa berkemampuan sedang, dan 1 siswa berkemmampuan rendah. Ahl ini dilakukan karena pembelajaran dengan menggunakan model TSTS bertujuan untuk saling belajar ( peer tutoring) dan saling mendukung).

2. Guru memberikan subpokok bahasan pada tiap-tiap kelompok untuk dibahas brsama-sama dengan anggota kelompok masing-masing.

3. Siswa bekerja sama dalam kelompok yang beranggotakan empat orang. Hal ini berujuan untuk memberikan kesempatan kepada siswa untuk dapat terlibat secara aktif dalam proses berpikir.

4. Setelah selesai, dua orang dari masingmasing kelompok meninggaalkan kelompoknya untuk bertamu kke kelompok lain.

5. Dua orang yang tinggal dalam kelompok bertugas membagikan hasil kerja dan informasi mereka kepada tamnu dari kelompok lain.

6. Tamu, mohon diri dan kembali ke kelompok mereka sendiri untuk melaporkan temuan mereka dari kelompok lain.

7. Kelompok mencocokan dan membahasa hasil-hasil kerja mereka.

8. Masing-masing kelompok
Dengan mengetahui hal tersebut guru dapat menerapkan model pembelajarn tersebut di dalam kelas. Dengan demikian siswa jaga dapat menganalisis puisi dengan baik dan benar. Dalam menganalisis puisi siswa harus mampu memahami puisi dan menafsirkan makna dalam sebuah puisi. Dengan melakukan hal tersebut siswa akan mampu untuk menganalisis sebuah puisi.

Arti istilah analisis (analysis) dianggap berkaitan erat dengan pengertian evaluasi terhadap situasi dari sebuah permasalahan yang dibahas, termasuk di dalamnya peninjauan dari berbagai aspek dan sudut pandang.

Evaluasi merupakan tahap pertama dimana system engineering menganalisis hal-hal yang diperlukan dalam pelaksanaan proyek pembuatan atau pengembangan system dalam bidang komunikasi dan komputerisasi.

Dalam komputasi, analisis ini biasanya mencakup segi kontrol arus, kontrol kesalahan dan penelitian efisiensi. Tidak jarang ditemui permasalahan besar dapat dibagi menjadi komponen yang lebih kecil sehingga dapat diteliti dan ditangani lebih mudah. Lihat juga flow analysis, numerical analysis, system analysis.

Dalam linguistik, analisa atau analisis adalah kajian yang dilaksanakan terhadap sebuah bahasa guna meneliti struktur bahasa tersebut secara mendalam. Sedangkan pada kegiatan laboratorium, kata analisa atau analisis dapat juga berarti kegiatan yang dilakukan di mempresentasikan hasil kerja mereka. 
laboratorium untuk memeriksa kandungan suatu zat dalam cuplikan.

Karya sastra, termasuk puisi, adalah sebuah struktur. Sebuah struktur menyiratkan adanya unsur-unsur pembentuk. Puisi adalah sebuah struktur yang kompleks, yang terdiri atas unsur-unsur yang saling berjalinan dengan erat. Unsur-unsur itu tidak berdiri sendiri-sendiri. Sebuah unsur hanya mempunyai arti dalam kaitannya dengan unsur-unsur lainnya di dalam struktur itu dan kaitannya dengan keseluruhannya. Unsur dalam struktur adalah unsur fungsional, yaitu mempunyai tugas (fungsi) tertentu dalam menyusun struktur.

\section{METODE PENELITIAN}

Metode yang dilakukan dalam penelitian ini yaitu metode eksperimen yang merupakan kegiatan terinci yang direncanakan untuk menghasilkan data untuk menjawab suatu masalah atau menguji suatu hipotesis. Menurut Syaiful Bahri Djamarah (1995) menyatakan bahwa "Metode eksperimen adalah cara penyajian pelajaran dimana siswa melakukan percobaan dengan mengalami dan membuktikan sendiri sesuatu yang dipelajari”. Metode Eksperimen dilakukan dengan model pembelajaran two star to stray (TS-TS), sesuai dengan judul penelitian.

\section{PEMBAHASAN}

Dalam penelitian ini Populasi yang digunakan adalah siswa kelas $\mathrm{X}$ yang berjumlah 80 orang, sebagai total sampling sebanyak 80 orang dan dibagi menjadi dua kelompok yaitu kelompok kelas kontrol dan kelompok eksperimen. Metode yang digunakan dalam penelitian ini adalah metode eksperimen yaitu metode two group design post-test. Instrumen yang digunakan adalah esay tes atau tes tertulis yaitu menganalisis puisi karangan bunga karya Taufiq Ismail.

Berdasarkan hasil penelitian kesulitan dalam menganalisis sebuah puisi dapat dilihat dari segi guru yang tidak menggunakan model pembelajaran yang tepat dalam proses pembelajaran di kelas. Dengan demikian peneliti menawarkan model pembelajaran two star to stray untuk dapat menganalisi sebuah puisi dengan baik.

\section{KARANGAN BUNGA}

Karya Taufiq Ismail, 1966

Tiga anak kecil

Dalam langkah malu-malu

Datang ke Salemba

Sore itu

"Ini dari kami bertiga

Pita hitam pada karangan bunga

Sebab kami ikut berduka

Bagi kakak yang ditembak mati

Siang tadi!"

Berikut akan dijelaskan analisisi puisi "Karangan Bunga " Taufik Ismail.

Pada tahap ini sebuah karya sastra dikritik dengan melihat unsur intrinsik karya sastra adalah sebagai berikut: 


\section{Tema}

Tema yang terdapat dalam puisi ini adalah kepahlawanan.

\section{Latar/setting}

Terjadi pada siang hari, bertempat di Salemba (Universitas Indonesia).

3. Tokoh

Terdapat dua tokoh dalam puisi ini, yakni tokoh utama dan tokoh figuratif. Secara konotatis tokoh utamanya adalah tiga anak kecil sedangkan tokoh figuratifnya adalah kakak yang ditembak mati.

4. Rima

Menggunakan rima bebas.

\section{Diksi}

Mempunyai kata-kata berkonotasi (tidak sebenarnya).

\section{Citraan}

Puisi ini menggunakan citraan penglihatan.

\section{Majas/Gaya Bahasa}

Majas yang digunakan dalam puisi ini adalah majas perbandingan/asosiasi. Hal ini terlihat pada bait pertama baris pertama "tiga anak kecil" yang menggambarkan tiga tuntutan rakyat (Tritura). Juga terdapat pada judul puisi itu sendiri serta pada bait kedua baris kedua. Hampir semua kalimat dalam puisi ini menggunakan majas asosiasi.

8. Angkatan

Puisi ini berada pada angkatan '66. Terdapat dalam kumpulan puisi Tirani oleh Taufik Ismail sering mengangkat masalah demonstrasi dan PKI.
9. Sajak

Sajak dalam puisi ini adalah sajak bebas.

\section{Tahap Penafsiran}

\section{Parafrase}

Ada tiga orang anak kecil. Melangkah dalam langkah yang malu-malu. Mereka bertiga datang ke Salemba (Universitas Indonesia), pada sore hari tadi. Semua ini adalah pemberian dari kami bertiga dengan pita hitam yang diikatkan pada sebuah karangan bunga. Sebab kami ikut berduka dan merasa sedih. Ini adalah sebuah rasa kepedulian bagi kakak yang ditembak mati karena berdemo memperjuangkan Hak Asasi Manusia lain. Pada siang hari tadi.

\section{Tafsiran}

Karangan bunga mengingatkan kita pada rangkaian bunga-bunga yang melambangkan dua peristiwa dalam hidup manusia yaitu peristiwa suka dan duka. Yang membedakan dari keduanya adalah adalah warna dan tulisan. Untuk peristiwa duka biasanya menggunakan warna-warna mati seperti ungu, abu-abu, dan merah tua dengan disertakan tulisan duka cita. Sebaliknya, pada peristiwa suka cita biasanya orang-orang menggunakan warna-warna cerah seperti putih, hijau, dan kuning yang disertai dengan tulisan selamat.

Dalam konteks puisi ini, karangan bunga sudah sangat menunjukkan kenyataan turut berduka cita atas meninggalnya seorang pahlawan. Boleh jadi, puisi menjadi sebuah karangan bunga dari seorang Taufik Ismail 
sebagai ungkapan turut berbelasungkawanya atas kepergian seorang sahabat. Setidaknya karangan bunga ini tidak menjadi rusak atau lapuk dimakan waktu tetapi tetap dikenang oleh generasi-generasi selanjutnya.

\section{Tahap Analisis}

Pada tahap ini analisis yang dilakukan adalah mengungkapkan setiap kalimat yang ada pada tiap bait dari kalimat yang bermakna konotatif menjadi kalimat yang bermakna denotatif.

Adapun hasil analisisnya adalah sebagai berikut:

"Tiga anak kecil/dalam langkah malumalu/datang ke Salemba/sore itu" memiliki makna yang sangat berbeda dari tulisan harfiahnya. Tiga anak kecil adalah simbol Tritura yang diteriakkan oleh rakyat karena Indonesia telah terlalu lama tunduk pada pemerintahan Soekarno dan takut untuk berubah (inilah yang dilambangkan "dalam langkah malu-malu). Sementara Salemba adalah simbol perjuangan rakyat, karena pada waktu itu dijadikan markas kami. Selain itu juga menjadi tempat dimakamkannya jenazah Arif Rahman Hakim.

Bait kedua: "'Ini dari kami bertiga/pita hitam pada karangan bunga/sebab kami ikut berduka/bagi kakak yang ditembak mati/siang tadi!" lebih bersifat sugestif (bahasa yang menyaran dan memengaruhi pikiran pembaca) dan juga bersifat asosiatif (mampu membangkitkan pikiran dan perasaan yang mempengaruhi pada peristiwa penembakan Arif Rahman Hakim, karena Taufiq mengatakan, "bagi kakak yang ditembak mati siang tadi!"

\section{Tahap Evaluasi}

Berdasarkan analisis di atas kita dapat menemukan keunggulan dari puisi tersebut, yakni:

1. Puisi ini tidak sekedar sebuah imajinasi penyair tetapi lebih mengangkat sebuah realita sosial.

2. Kata-katanya familiar namun membutuhkan kontemplasi yang mendalam. Artinya, pembaca seolah-olah diajak untuk merenungi tragedi yang terjadi saat itu.

3. Diksi yang dipilih oleh Taufik Ismail sangat unik dan lebih condong ke makna konotasinya.

4. Puisi ini lebih bersifat sugestif (bahasa yang menyaran dan memengaruhi pikiran pembaca) dan juga bersifat asosiatif (mampu membangkitkan pikiran dan perasaan yang merembet pada peristiwa penembakan Arif Rahman Hakim, karena Taufik mengatakan, "bagi kakak yang ditembak mati siang tadi”).

Adapun kelemahan yang terdapat di dalam puisi tersebut adalah jika dilihat secara tersurat, kita akan melihat setiap kata maupun kalimat pada tiap barisnya adalah kata atau kalimat yang sangat dekat dengan kita. Namun, jika ditilik dari segi penafsiran dan analisis maka kita akan cukup merasakan kesulitan dalam menganalisisnya karena di dalamnya menggunakan kata-kata berkonotasi yang cukup 
rumit apalagi jika tidak mengetahui latar belakang ditulisnya puisi ini.

Kemampuan menganalisis dari seorang pengkritik akan lebih diasah dan mungkin membutuhkan waktu yang cukup lama untuk menganalisisnya.

\section{HASIL PENELITIAN}

Dari hasil pengolahan data diperoleh rata-rata kelas eksperimen adalah 76,87 dengan standar deviasi 9,90, sedangkan kelas kontrol 56 dengan standar deviasi 8,15. Dengan demikian dapat dikatakan bahwa nilai kelas eksperimen lebih tinggi dari kelas kontrol.

Setelah dilakukan pengujian hipotesis diperoleh $t_{\text {hitung }}=10,33$ selanjutnya dikonsultasikan dengan $t_{\text {tabel }}$ pada taraf signifikan 5\% dengan $\mathrm{dk}=\left(\mathrm{n}_{1}+\mathrm{n}_{2}\right)-2=(40+40$ $-2)=78$, maka diperoleh taraf signifikan $5 \%=$ 1,982 (dengan interpolasi). Kemudian dibandingkan antara $t_{\text {hitung }}$ dengan $t_{\text {tabel }}$ diperoleh $t_{\text {hitung }}>t_{\text {tabel }} 10,33>1,982$ sehingga dapat disimpulkan bahwa $\mathrm{Ha}$ diterima yaitu menyatakan bahwa model Two Stay Two Stray (TS-TS) dapat diterapkan untuk meningkatkan kemampuan siswa dalam menganalisis sebuah puisi yang berjudul Karangan Bunga karya Taufiq Ismail pada siswa kelas X SMK PAB 3 Medan.

\section{PENUTUP}

\section{A. Kesimpulan}

Berdasarkan hasil penelitian yang telah diuraikan, maka dapat disimpulkan:
1. Pemerolehan rata - rata kemampuan menganalisi puisi siswa kelas X SMK PAB 3 Medan Estate dengan menggunakan model Two Stay Two Stray adalah 76,87 pada kategori Baik

2. Dari hasil pengolahan data diperoleh rata - rata kelas eksperimen adalah 76,87 dengan standar deviasi 9,90, sedangkan rata - rata kelas kontrol 56 dengan standar deviasi 8,15. Dengan demikian dapat dikatakan bahwa nilai kelas eksperimen lebih tinggi dari kelas kontrol. Setelah dilakukan pengujian hipotesis diperoleh $t_{\text {hitung }}=10,33$ selanjutnya dikonsultasikan dengan $t_{\text {tabel }}$ pada taraf signifikan $5 \%$ dengan $\mathrm{dk}=($ $\left.\mathrm{n}_{1}+\mathrm{n}_{2}\right)-2=(40+40-2)=78$, maka diperoleh taraf signifikan $5 \%=1,982$ (dengan interpolasi). Kemudian dibandingkan antara $t_{\text {hitung }}$ dengan $t_{\text {tabel }}$ diperoleh $t_{\text {hitung }}>t_{\text {tabel }} 10,33>1,982$ sehingga dapat disimpulkan bahwa hipotesis diterima yaitu menyatakan bahwa model Two Stay Two Stray (TSTS) dapat diterapkan untuk meningkatkan kemampuan siswa dalam menganalisis puisi.

\section{B. Saran}

Berdasarkan temuan dalam penelitian ini, saran-saran yang ingin disampaikan melalui penelitian ini adalah sebagai berikut.

1. Lembaga pendidikan disarankan untuk menggunakan penelitian ini sebagai referensi yang dapat memberikan 
sumbangan positif bagi

perkembangan dan kemajuan ilmu

pengetahuan khususnya berkaitan dengan menganalisis sebuah puisi.

2. Para guru disarankan untuk lebih cermat dalam mengajarkan analisis puisi.

3. Penelitian Lain disarankan untuk mengembangkan dan melakukan penelitian lanjutan dengan memperluas masalah dan situs penelitian dengan demikian, hasil penelitian ini menjadi lebih luas dan dapat dipertanggungjawabkan secara ilmiah.

4. Berdasarkan paparan tersebut disarankan penelitian lain untuk mengadakan penelitian lanjutan terkait analisi puisi.

\section{DAFTAR PUSTAKA}

Arikunto, $\quad$ Suharsmi.2006.Prosedur Penelitian Suatu Pendekatan Praktik.Jakarta: Rineka Cipta.

Hartoko, Dick.1986.Pemandu di Dunia Sastra.Yokyakarta:Kansius.

Huda, Miftahul.2014.Model-model pengajaran dan pembelajaran.Yogyakarta:Pustaka Belajar.

Kosasi E.2003.Kompetensi Ketatabahasan dan Kesusastraan.Bandung:Yrama Widya. Poerwadarminta.2007.Kamus Umum Bahasa Indonesia.Jakarta:Balai Pustaka. Sugiyono.2010.Metode Penelitian Kuantitatif Kualitatif dan $R \& D$.Bandung: Algabeta
Sugiyono.2011.Statistika

Penelitian.Bandung:Alfabeta,cv.

Suwarna,dadan.2012.Trik menulis puisi,cerpen,resensi buku,opini/esai. Tangerang:Jelajah Nusa

Waluyo, Herman S.2005.Apresiasi Puisi.Jakarta: Gramedia. 